\title{
The 2007 Solar America Cities Awards
}

\section{About the Awards}

On June 20, 2007, the U.S. Department of Energy (DOE) named thirteen U.S. cities as inaugural Solar America Cities. DOE recognizes Solar America Cities as partners highly committed to solar technology adoption at the local level. The awards are intended to accelerate solar adoption in our nation's electricity load centers by supporting cities' innovative efforts with financial and technical assistance. The cities selected are prepared to take a comprehensive, city-wide approach to solar technology that facilitates its mainstream adoption.

The Solar America Cities will receive a combined \$2.5 million in federal financial assistance. DOE will also provide additional value in the form of on-site technical and policy expert assistance to help cities with their most pressing needs. Technical assistance is provided by DOE, its national laboratories, and other experts in areas such as city planning, technology selection, project financing, building codes, architecture, and community outreach.

Solar technologies promoted by Solar America Cities include photovoltaics, concentrating solar power, and solar water/air heating technologies.

This 675-kW photovoltaic array on the Moscone Center in San Francisco, CA, converts sunlight directly into electricity. Credit: PowerLight Corporation.

\section{What Cities Won?}

The winning cities for 2007 are the following: Ann Arbor, MI; Austin, TX; Berkeley, CA; Boston, MA; Madison, WI; New Orleans, LA; New York, NY; Pittsburgh, PA; Portland, OR; Salt Lake City, UT; San Diego, CA; San Francisco, CA; and Tucson, AZ.

\section{Why were These 13 Selected?}

Each city submitted a proposal outlining its plans to build a sustainable solar infrastructure, streamline city-level regulations, and promote the adoption of mainstream solar technology among residents and businesses. Cities were selected competitively. Evaluation criteria focused on demonstrating a comprehensive city government approach to solar planning, including methods to further market expansion and to remove local market barriers. Selected cities demonstrated a high level of commitment to promote solar power throughout the city, involving local government officials, utilities, and private partners.

\section{What are the Desired Outcomes?}

- Development of a comprehensive city government approach to solar implementation, involving key stakeholders, utilities, and private partners

- A widespread increase in solar power use

- Large-scale solar installations

- A reduction in market barriers through activities such as streamlining solar-friendly permitting and zoning

- Creation of city-level solar incentives (e.g., solar rebates, financial assistance, tax credits, property tax abatements, and/or tax incentives to solar manufacturers who locate in the city)

- An increase in public awareness through promotions and citywide education

- Inclusion of renewable energy curriculum material in public schools

- Integration of solar energy into city planning and emergency preparedness plans (e.g., schools as shelters or natural disaster relief)

- Solar America Cities will serve as models for other cities. 


\section{SAI Across America}

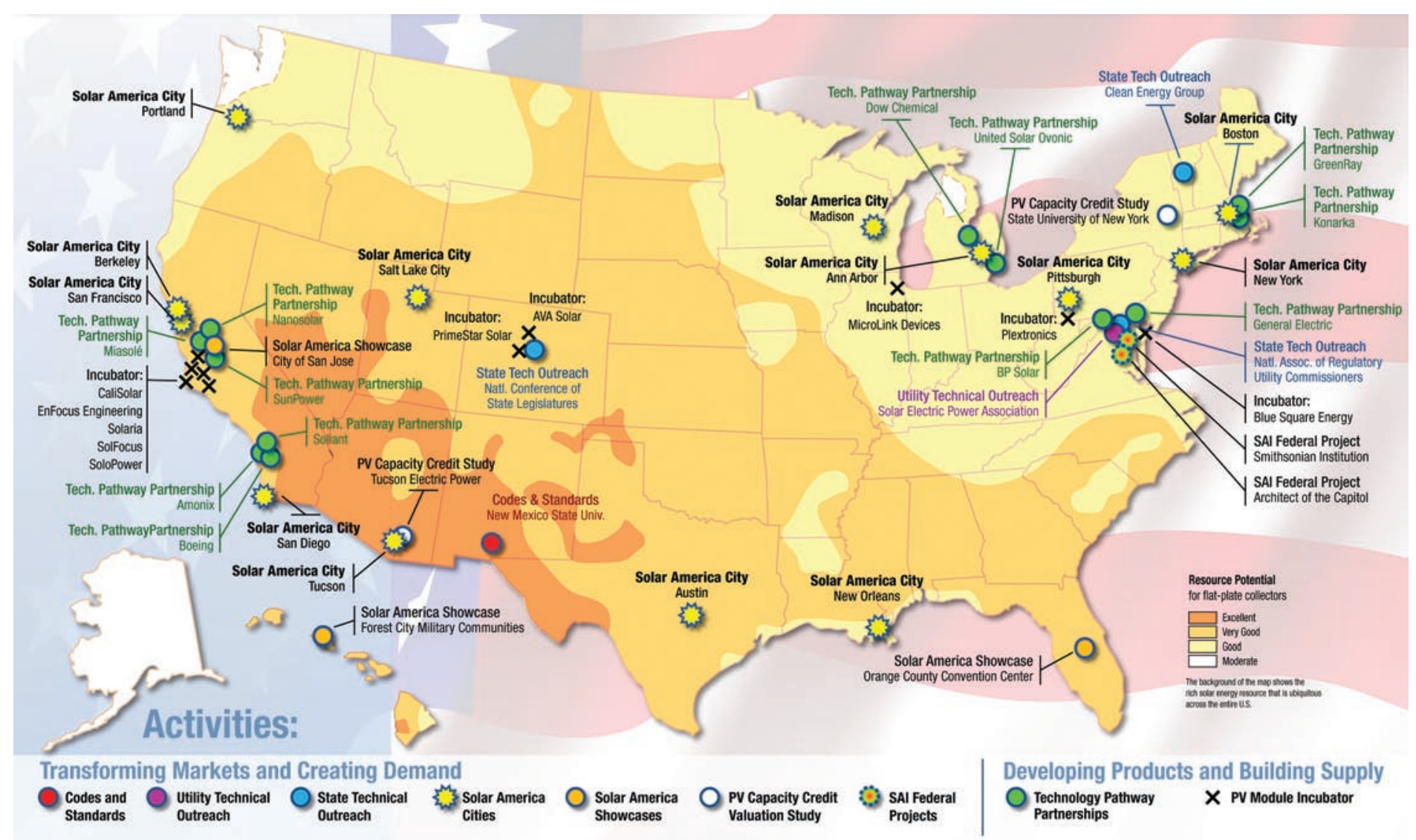

\section{About the Solar America Initiative}

The Solar America Cities awards are part of the Market Transformation efforts of the Solar America Initiative (SAI). President Bush launched SAI in 2006 to accelerate the development of advanced solar technologies, including photovoltaics and concentrating solar power systems, with the goal of making them cost-competitive with conventional forms of electricity, e.g., coal and natural gas.

The Market Transformation focus of SAI addresses marketplace barriers and offers solar technologies the opportunity for market expansion. The other areas of SAI deal with research and development of solar technology including innovative devices and processes, prototype PV components, and collaborative research and development activities among industry, university, and DOE's national laboratories.

\section{Resources}

Office of Energy Efficiency and Renewable Energy: www.eere.energy.gov/ Solar America Initiative: www.eere.energy.gov/solar/solar_america EERE Solar Program: www.eere.energy.gov/solar/photovoltaics.html Database of State \& Local Incentives for Renewable Energy: www.DSIREUSA.org Solar America Tour: www.eere.energy.gov/solar/solar_america EERE State Activities \& Partnerships: www.eere.energy.gov/states NREL Solar Energy Basics: www.nrel.gov/learning/re_solar.html American Solar Energy Society (ASES): www.ases.org Interstate Renewable Energy Council (IREC): www.irecusa.org/ U.S. Green Building Council (USGBC): www.usgbc.org

Sponsored by the

U.S. Department of Energy, Office of Energy Efficiency and Renewable Energy

For more information contact:

EERE Information Center

1-877-EERE-INF (1-877-337-3463)

www.eere.energy.gov

Prepared by the

National Renewable Energy Laboratory (NREL)

NREL is a U.S. Department of Energy National Laboratory

Operated by Midwest Research Institute $\bullet$ Battelle

\section{DOE/G0-102007-2441 • June 2007}

A Strong Energy Portfolio for a Strong America. Energy efficiency and clean, renewable energy will mean a stronger economy, a cleaner environment, and greater energy independence for America. Working with a wide array of state, community, industry, and university partners, the U.S. Department of Energy's Office of Energy Efficiency and Renewable Energy invests in a diverse portfolio of energy technologies.

Printed with a renewable-source ink on paper containing at least $50 \%$ wastepaper, including $10 \%$ postconsumer waste. 